\title{
KFI SZAKPOLITIKA ÉS A HATÁRON TÚLI MAGYARSÁG
}

Dr. Szabó István - Rigó-Ditzendy Orsolya - Dr. Cziráki Szabina

\section{ABSZTRAKT}

A tudomány természeténél fogva mindig változik, hiszen új eredményeket hoz létre. A digitalizáció, a publikációs boom, vagy akár a kutatási eszközök jelentős átalakulása azonban a tudománymúvelés módjának változását is magával hozta. Ezeket a változásokat, aktuális kérdéseket ismertetjük a következőkben. A kormányzat számos olyan intézkedést hozott, amelyek választ adhatnak a felmerülő problémákra. Ezek közül kiemelkedik az ún. Tématerületi Kiválósági Program rendszere, amely célul tűzte ki, hogy az intézmények fókuszálják erőforrásaikat, erősítve a KFI multi- és interdiszciplináris jellegét. Az egyéni kutatói kiválóságot pedig a kezdeti lépéseknél, a felsőoktatási hallgatók között az Országos Tudományos Diákköri Konferencia segíti kifejteni, ezzel biztosítva a tudományos utánpótlást. Rövid tanulmányunkkal inspirációt szeretnénk nyújtani a megváltozott körülmények között olyan lehetőségek felfedezéséhez, amelyek segíthetik a magyar tudomány határok nélkül való művelését.

\section{A KFI SZAKPOLITIKA AKTUÁLIS KÉRDÉSEI}

A tudományos kutatások jelentősége nem kizárólag a tudományos eredményekben rejlik. Ahhoz, hogy a tudományos eredményességig eljuthassunk, számos feltételnek kell teljesülnie. $S$ bár természetesen az eredmények azok, amelyek objektív és mérhető célként szolgálnak, ugyanakkor az is fontos, miként jut el egy-egy kutatás az eredményességig. Az alábbiakban ezeket a feltételeket kívánjuk sorra venni, amelyek közül számosat a Nemzeti Kutatási, Fejlesztési és Innovációs Hivatalon keresztül tud biztosítani az állam a kutatók számára.

A kutatóknak sokféle eszközt kell igénybe venniük ahhoz, hogy munkájuk során elörehaladjanak. Az eredményesség egyik nem elhanyagolható akadálya az úgynevezett bizonytalansági faktor, jelesül, hogy előre csak valószínűsíteni lehet eredményeket, tudni azonban bizonyossággal nem. ${ }^{1}$ Természetszerúleg ez azt is jelenti, hogy néhány kutatás vakvágányt jelent utólag, mégis, ugyanazokat az eszközöket veszik használatba, amelyekkel sok eredményesnek mondható kutatást is lefolytatnak.

${ }_{1}^{1}$ OECD (2015): Frascati Manual 2015. Paris, OECD Publishing, 2015. DOI: $10.1787 / 9789264239012$-en 
Az eszközök biztosításában fontos szerepet játszik a magyar állam, így a Hivatal is. Fontos kérdés, mit értünk eszközhasználaton, mit jelent, hogy a kutatásokhoz infrastruktúrát kell biztosítanunk.

Az eszközök alatt meglehetősen széles spektrumra kell gondolnunk, amelynek jelentős részét képezik azok a kézzelfogható, fizikai „,kellékek”, amelyek jellemzően a kutatáshoz használt infrastruktúrák, kutatási eszközök. Ezeket a modern felfogásban már átfogóan értelmezzük. Í Így egyrészről infrastruktúra például egy adatbázis is, mivel az adatokon alapuló kutatás minden tudományterületen elengedhetetlen feltétel. Másrészről a kutatási infrastruktúra részét képezik ugyanúgy azok a személyek is, akik annak működtetését, illetve használatát lehetővé teszik.

Továbbá eszköznek kell tekintenünk a kutatásra rendelkezésre álló forrásokat is, hiszen ezek nélkül a kutatások jelentős része nehezen, egy részük pedig egyáltalán nem tudna megvalósulni. Ezeket a forrásokat jellemzően az egyéni kiválóság mentén ítélik oda tudományos testületek (kollégiumok) javaslatára a tudományfinanszírozásban érintett szervezetek, így például a Nemzeti Kutatási, Fejlesztési és Innovációs Hivatal által múködtetett Országos Tudományos Kutatási Alapprogramok szakterületi kollégiumai, vagy a Magyar Tudományos Akadémia Bolyai Kuratóriuma.

Fontos tehát az „egyéni kiválóság” kérdése, ami a korábbi tudományos teljesítmény és a jövőbeli várható tudományos teljesítmény összegét jelenti. Ezt első körben a kutatási terveket bírálóknak kell megítélni többkörös bírálati rendszer keretében. Ez a többlépcsős bírálati rendszer arra hivatott, hogy egy-egy kutatás minél több szereplő által kerüljön validálásra (a tudományos eredményesség viszonylagossága, nehéz kvantifikálhatósága miatt), majd támogatási javaslattételre.

Ugyanakkor számolnunk kell bizonyos mértékű paradoxitással is, amely minden kutatásfinanszírozási rendszerben jelen van, mivel - ahogy korábban említettük - egy bizonytalan kimenetelű kutatásra kell a pályázóknak vállalást tenniük mint jó eredménnyel teljesülő kutatásra. Ezt a kockázati elemet kívánja a bírálati rendszer oly módon ellensúlyozni, hogy a kutató korábbi eredményessége bizalomra ad okot, akár csak egy jó minőségú márkanév esetében. Ez persze magában hordozza a "Máté-elv”, azaz, „akinek van, annak adatik”3 teljesülését is, és így alakul ki a „pályázóképes kutatók” szűk köre. Ugyanakkor a jó teljesítmény, a kiválóak közé kerülés a kutatók számára egységesen nyitott, tehát így is biztosít egyfajta átjárhatóság. Éppen a teljesítményelvűség biztosíthatja azt, hogy nem kell totálisan „kasztos”, zárt rendszerrel számolni, amely végeredményben meg-

\footnotetext{
2 GRINIECE, Elina - Alasdair REID - Jelena ANGELIS: Evaluating and Monitoring the Socio-Economic Impact of Investment in Research Infrastructures. Technopolis Group, 2015. DOI: 10.13140/RG.2.1.2406.3525/1

${ }^{3}$ MERTON, Robert K.: The Matthew Effect in Science, II. Cumulative Advantage and the Symbolism of Intellectual Property = Isis, 79. évf. 4. sz. 1988. 606-623. p.
} 
gátolná a fejlődést. Az egyéni pályázatoknál az is lényeges szempont, hogy nincsenek előre, központilag dedikált kutatási célok, azaz a kutatói kíváncsiságnak csak a kutatás tudományos oldalról történő értékelése szabhat gátat - nevezetesen, hogy a kutatásnak tudományos értelemben várható-e valamiféle haszna.

Az eredményesség egyik legfontosabb mutatója a publikációk mennyisége és minősége, amelynek viszont előfeltétele a szakirodalmi forrásbázis használata, így elmondható, hogy a fizikai eszközök közül ez kiemelkedőnek tekinthető. Arról külön értekezést lehetne írni, mennyire erősen termelésjelleget öltött mára a tudomány, és emiatt mennyire nehéz igazán újszerű, áttörő eredményeket publikálni (Id. „publish or perish” elv). A publikációs kényszernek nevezett jelenség nyomán ugyanakkor egyre több és több folyóirat, publikációs felület jön létre, amelyek között azonban nem könnyű az eligazodás. Az open access ${ }^{4}$, azaz a nyílt hozzáférés megjelenésével a szakirodalom elérése új szintre lépett ugyan, azonban az irodalom validálását, értékes voltát még mindig az irodalmat publikáló fórum rangja garantálja elsősorban (ami a nagy kiadók oligopol helyzetét is biztosítja). Ezt a helyzetet erősíti, hogy a publikációs kényszer olyan kezdeményezéseket is hozott, amelyek úgy kívánják kielégíteni a publikálásra vonatkozó piaci keresletet, hogy a minőségi szűrőt jóformán eltüntetik. ${ }^{5}$ A probléma következő lépcsőjét az open data repository jelenti majd, ami ugyan még csak gyerekcipőben jár, azonban korábban megkérdőjelezhetetlennek tartott paradigmákat döntöget. A „scientia potentia est” (a tudás hatalom) elve a tudományban is érvényesül az adatok kapcsán, hiszen a kutatások egyik kulcsa szinte minden esetben az adott kutatási kérdést megválaszoló adat elóállításának képessége. Érthető módon ennek megosztása, közzététele bizonyos hátrányt is jelenthet a kutató személyi szintjén - azzal együtt, hogy közösségi szinten nyilvánvaló előnyökkel is jár, mivel lehetőség nyílik új adatokkal való egybekapcsolásra, eddig fel nem tárt összefüggések megismerésére interdiszciplináris módon. Annak ellenére, hogy a publikációs kényszer erősen jelen van a kutatók életében, a megismételt kutatások általában nem vonzó lehetőségek a kutatók számára. Ez érthető, hiszen ha az eredmény ugyanaz, mint korábban, a kutató már csak mint másodlagos szereplő tud megjelenni egy adott területen. Ennek ellenére a fizika területén ez például az alkalmazott protokoll, miszerint egy-egy eredményt - pl. új részecske felfedezését - csak két vagy több független kísérlet nyomán ismernek el. Társadalomtudományi területen számos esetben a kísérletek megismétlése évtizedes sarokkőnek tekinthető kutatási eredményeket döntött meg. ${ }^{6}$ Fontos látni ugyanakkor, hogy ezek nem azonos adatokon végzett kontroll-kutatások voltak, ami az open data koncepció részét képezi.

\footnotetext{
4 BILICSI Erika - DÉR Ádám - LENCSÉS Ákos: Az Open Access támogatásának közép-európai gyakorlata. = Könyv, Könyvtár, Könyvtáros, 25. évf. 2. sz. 2016. 20-28. p.

5 BEALL, Jeffrey: Dangerous Predatory Publishers Threaten Medical Research. = Journal of Korean Medical Science, 31. évf. 10. sz. 2016. 1511-1513. p. DOI: $10.3346 / \mathrm{ikms} .2016 .31 .10 .1511$

6 REICHER, Stephen D. - S. Alexander HASLAM - Arthur G. MILLER: What Makes a Person a Perpetrator? The Intellectual, Moral, and Methodological Arguments for Revisiting Milgram's Research on the Influence of Authority = Journal of Social Issues. 70. évf. 3. sz. 2014. 393-408. p. DOI: $10.1111 /$ josi.12067
} 
A szakirodalom megkerülhetetlensége az oka talán annak is, hogy az azokhoz való hozzáférés alapvető adottságnak tűnhet, holott ez messze nincs így. A kormányzat 2020ban több mint 4,5 milliárd forint összegben járult hozzá a tudományos tartalmakhoz való hozzáférés biztosításához az EISZ program keretében. Amikor alapkutatásokról, kutatásfinanszírozásokról beszélünk, fontos, hogy lássuk, ez az összeg is nagyban elősegíti a tudomány művelését, még ha sokszor el is felejtkezünk róla. Természetesen az open access megoldást jelenthetne erre a kérdésre, de az open access kapcsán is fontos tudni, hogy az annyiban nyílt (open), hogy a kutatónak nincsenek további költségei (ami lényeges!), de fizetni ezért is kell az EISZ szintjén.

$A z$ „eszközök” - és itt indokolt az idézőjel - sorában itt érünk el a legfontosabbhoz, a tudományos közösséghez, azaz a kutatókhoz. A tudományos eredmények elérése, azok validálása, a támogatások megítélése, mind-mind a kutatók együttmúködésének köszönhető. Enélkül nem érhető el komoly tudományos eredmény; még az olyan, látszólag "magányos" kutatási területeken sem, ahol úgymond „egyszemélyben is" el lehet érni eredményeket, látható, hogy számos esetben az együttmúködés megkerülhetetlen. Bizonyos tudományokban pedig, föleg „big science” esetében (pl. CERN) az egyéni kutatás elképzelhetetlen.

A fentiekből is látható, hogy a kutatás egy többszereplős játék, amely bizalmon és nyitottságon alapul. Éppen ezért különösen fontos, hogy Magyarország a határon túli magyar kutatókat is be tudja vonni a hazai kutatások világába. A határon túli kutatók támogatásában fontos elem az, hogy hozzáférjenek azokhoz a magyar nyelvú irodalmakhoz, amelyek egyébként nem lennének számukra elérhetőek. Ráadásul ezek az irodalmak csak magyarul elérhetőek - témájuknál fogva (nyelvészet, társadalom, történelem, irodalom stb.) elsősorban inkább nemzeti jellegűek, sőt a nemzettudat, az összetartozás kulcselemét is alkotják.

Jól látható, hogy nem „csak” kutatásról van tehát szó, amikor a határon túli ügyeket Magyarország felkarolja az irodalmakhoz való hozzáférésben. A magyar nyelven történő kutatás, az anyaországgal való kapcsolat fenntartása, erősítése is kiemelten fontos cél mindannyiunk számára.

A hazai kutatási intézmények több formában is ápolják kapcsolataikat a határon túli magyarsággal. Ezek közül kiemelkedik az úgynevezett Tématerületi Kiválósági Program, amely lehetőséget nyújt a hazai intézményeknek, hogy tudományos erősségeiket intézményi szinten - a határon túli intézményekkel is közösen -összegyűjtve képesek legyenek jelentős hatású kutatási eredményeket elérni, valamint az Országos Tudományos Diákköri Tanács, amelynek egyik kiemelt missziója a határon túli magyar fiatalság kutatásainak elősegítése és a tudományos eredményeik számára a magyarországi hallgatókkal közös bemutatkozási fórum megteremtése. A következőkben ezeket vesszük sorra. 


\section{A TÉMATERÜLETI PROGRAMOK RENDSZERE}

Az NKFI Hivatal intézmények szintjén olyan támogatási programokkal rendelkezik, amelyek a magyarországi felsőoktatási intézmények, valamint kutatóintézetek kutatási kapacitását kívánják erősíteni. A kutatási kapacitások jelentik egyrészt a kutatási infrastruktúra fejlesztését, másrészt pedig - a fentiekben taglaltak jelentősége miatt - a hozzájuk való hozzáférhetőség kiszélesítését is. Mindezt nem önmagában kívánjuk megvalósítani, hanem úgynevezett tématerületi kutatásokon keresztül azt is biztosítani szeretnénk, hogy a résztvevő intézmények társadalmi kihívásokként definiált problémákra tudományos válaszokat keressenek.

A tématerület olyan, tudományágakat átfogó kutatási terület, amely aktuális, társadalmi-gazdasági, környezeti vagy technológiai problémákra keresi a választ. Ilyenek például a klímaváltozásból fakadó változások és nehézségek, vagy a jövő smart rendszerei, amelyek számos tématerületi kutatáshoz adnak fontos szempontokat. A tématerületek meghatározása során a kutatás-fejlesztés és innováció minden szegmensét szem előtt kell tartani, a kutatástól a piaci hasznosításig. A tématerületek kijelölése során előnyben kell részesíteni azokat a területeket, ahol a tudományos eredmények piacosítása valószínǔsíthető vagy folyamatban van. A tématerületi kutatási és innovációs programok legalább két, optimális esetben ennél több tudományág szoros együttműködésére épülnek.

Az intézményi kiválósági programok két támogatási konstrukciót ölelnek fel, a Felsőoktatási Intézményi Kiválóság Programot, valamint a Tématerületi Kiválósági Programot. A Felsőoktatási Intézményi Kiválósági Program keretében a korábbi, kutatóegyetemi rendszerre alapozva egy új, fókuszáltabb, tématerületi kiválóságra építő kutatástámogatási rendszer került kiépítésre. A 2018-ban, az Emberi Erőforrások Minisztériumában indult és 2019 óta az NKFI Hivatal koordinációjában folytatódó Program keretében a felsőoktatási intézmények az intézményfejlesztési tervük alapján meghatározott kutatási tématerületekre nyújthattak be pályázatot. A pályázat kifejezetten ösztönözte az interdiszciplinaritást és a kutatási tématerületek piacorientált jellegét. A piacorientált jelleg egyben nagyobb hangsúlyt kívánt fektetni az innovációs tevékenységre és az eredmények alkalmazhatóságára is.

A Programban 13 felsőoktatási intézmény 36 tématerületi kutatása részesült összesen 30 milliárd forint támogatásban 2018 és 2019 folyamán. A kutatási tématerületeken többek között a fenntartható gazdaság, a magyarországi vízgazdálkodás, az egészségügy, az agykutatás, a hazai vállalatok szerepének erősítése a nemzetgazdaságban, a gyógyszerkutatás, valamint a növénynemesítés témaköreiben folynak vizsgálatok.

A Nemzeti Kutatási, Fejlesztési és Innovációs Hivatal a Felsőoktatási Intézményi Kiválósági Program alapgondolatát továbbfejlesztve, azt kibővítve hirdette meg a Tématerületi 
Kiválósági Programot 2019-ben. A Program legfőbb célja a következő Uniós KFI finanszírozási keretprogram, a Horizon Europe keretrendszeréhez illeszkedő, kihívásokon alapuló kutatásfinanszírozási rendszer kialakítása. ${ }^{7}$

A társadalmi kihívásokként meghatározott célok az alábbiak:

1. Innováció a versenyképességért (fenntartható növekedés, technológia, ipar, innováció);

2. Tudomány a jövőnkért (tudomány a magyar közösségért, természeti és környezeti kihívások, nemzetközileg elismert tudományos eredmények, tudományos eredmények hasznosítása);

3. Nemzedékek életkilátásai (magyarság, népesedés, elöregedő társadalom, migráció, iskolázottság és mobilitás, egészségi állapot, ifjúság, életszínvonal, területi felzárkózás, családok és közösségek).

A kihívások sorában okkal jelenik meg a magyarság mint kulcselem, amellyel foglalkozni kell nemcsak kormányzati, de intézményi szinteken is. Hasonlóképpen a magyar közösségért végzett tudomány sem ismer földrajzi határokat, hiszen a magyarság nem földrajzi, hanem lelkületi kérdés.

A társadalmi kihívásokon túl a tématerületi kutatásoknak a következő négy kutatási terület valamelyikébe is illeszkedniük kell:

1. Biztonságos társadalom és környezet (agrártudomány, biotechnológia, hadtudomány, kiberbiztonság és információbiztonság, migráció, klíma és energetika, víz, földtudományok, űrkutatás, körkörös gazdaság);

2. Egészség (orvostudományi és állatorvos-tudományi kutatások, gyógyszerkutatások, biológia, biotechnológia, kémia, transzlációs medicina, agykutatás, rákkutatás, biztonságos élelmiszer);

3. Ipar és digitalizáció (mesterséges intelligencia, infokommunikáció, modern termelésiés gyártásrendszerek, kooperatív irányítás, mobilitás (közlekedés, logisztika, szállítmányozás), műszaki és mérnöki tudományok, matematika, fizika);

4. Kultúra és család (magyar nyelv és magyarság, társadalomtudomány és gazdaságtudomány, bölcsészet- és humántudományok, neveléstudomány és pszichológia, múvészetek).

A Tématerületi Kiválósági Programban 2019-ben 27 intézmény 55 kutatási tématerülete mintegy 14,6 milliárd forint értékben kapott támogatást.

A fentebb vázolt pályázati konstrukció célja, hogy az állami kutatás-fejlesztési ráfordítások a magyar társadalom legfontosabb kérdéseire keressenek lehetséges válaszokat.

7 MAZZUCATO, Mariana. (2018). Mission-Oriented Research \& Innovation in the European Union. A Problem-Solving Approach to Fuel Innovation-Led Growth. Brussels, European Commission, 2018. DOI: 10.2777/360325 
Általánosságban véve is megkérdőjelezhetetlen jelentőségűek az egészséggel kapcsolatos kutatások, amelyek között nem nehéz olyat találni, amely egyszerre felel meg a magas tudományos presztízsértéknek, ugyanakkor a társadalom számára is jól hasznosítható. Az egészséggel kapcsolatos kutatások a teljes pályázati program több mint harmadát fedik le. Ennek megfelelően többek között olyan tématerületi kutatásokat támogatunk, mint az emlőrák elterjedtségének visszaszorítása és hatékony gyógyításának lehetőségei, amelynek keretében az Országos Onkológiai Intézet vizsgálja annak lehetőségét, hogy a genetikai tényezők megismerésével hogyan lehetne megelőzni az emlőrák kialakulását; de megemlíthető a Debreceni Egyetem inzulin-rezisztenciával foglalkozó kutatása is.

Vannak szép számmal olyan kutatási tématerületek is, amelyek a magyar agrárium számára fontosak. Közöttük szerepel a Szent István Egyetem egyik tématerületi kutatása is, amely arról szól, hogy olyan, a megváltozott környezeti (klíma)feltételeknek megfelelő - így az új kórokozóknak ellenálló -, jól termő szőlőfajtákat nemesítsenek, amelyek lehetővé teszik, hogy a magyar borgazdaság továbbra is versenyképes maradjon. Az egyetem egy másik tématerületi kutatása a biztonságunkkal, a Balaton vízminőségével foglalkozik, azzal a céllal, hogy a vízben található mikroszennyeződéseket hatékonyabban szűrhessük ki, és így megvédhessük a Balaton és vízgyűjtője vízének kitűnő minőségét. A magyar gazdaság, turizmus és vízgazdálkodás kérdéseivel foglalkozó kutatásokat kiemelt jelentőségúként kezeljük.

Ösztönözni kívánjuk a Program keretei között azt is, hogy az egyetemek más KFI szereplővel együttműködésben dolgozzanak. Erre az egyik legjobb példa a Széchenyi István Egyetemen zajló kutatás, amely az autonóm közlekedési rendszerekkel foglalkozik, együttmúködve az Audi Hungária Kft.-vel, a Knorr-Bremse Fékrendszerek Kft.-vel, a ThyssenKrupp Presta Hungary Kft.-vel és a Robert Bosch Kft.-vel.

A legnagyobb, ipari területen szakosodott egyetemünk, a Budapesti Műszaki és Gazdaságtudományi Egyetem (BME) kutatási tématerületei között szerepel az intelligens gyártástechnológiák és a mesterséges intelligencia nyújtotta lehetőségek kutatása is. Ahhoz, hogy a jövőben ne csak leányvállalat-ország legyünk, alapvető a termelékenység fejlesztése, és ezzel Magyarország gazdasági versenyképességét is fokozzuk. Ebben meghatározó szerepet játszik a magas hozzáadott értéket teremtő intelligens gyártástechnológia kutatása és fejlesztése. A BME az automatizálási, a robottechnikai és az infokommunikációs technológiák (loT, cloud, 5G) alkalmazásának kutatásával azt kívánja lehetővé tenni, hogy a jövőben hatékonyan tudjuk kezelni a munkaerőhiányt, ráadásul ez a fejlesztési irány összhangban van a gyártórendszerek nemzetközi fejlődési trendjeivel is.

A korábban két külön pályázatként futó programot 2020-ban integráltuk, így ezek TKP2020, azaz Tématerületi Kiválósági Program 2020 néven, egyben folytatódnak tovább. Annak érdekében, hogy zökkenőmentes legyen az átmenet, ugyanakkor eleget tegyünk 
a nemzetközi tudományfinanszírozással kapcsolatos elvárásoknak is, két alprogramot hirdettünk meg a Programban. Az egyik a „bottom-up”, tehát az „alulról jövő” pillért képezi, amelybe azokat a tématerületi kutatásokat soroltuk, amelyeket az egyetemek intézményfejlesztési tervei alapján alakítottak ki. Ezzel a pillérrel kívánjuk biztosítani azt a fajta kutatói szabadságot, amelyben a döntő szó az intézményeknek jut. A másik alprogram a „top-down”, tehát a "felülről lefelé jövő" pillér jelenti: ennek az alprogramnak a keretében társadalmi kihívásokat definiáltunk, és a benyújtott tématerületi kutatások ezekre a kihívásokra kívánnak válaszokat találni.

A pályázatok elbírálása során fontos szempont a felsőoktatási intézmények és kutatóintézetek nemzetközi beágyazottságának erősítésére tett vállalás is. Bízunk abban, hogy a pályázati konstrukcióban rejlő kapcsolatépítési és tudományos társadalmi beágyazottságra irányuló lehetőséget arra is kihasználják majd az intézmények, hogy a környező országokban múködő magyar felsőoktatási intézményekkel és magyar kutatókkal szorosabb kapcsolatba kerüljenek.

\section{TUDOMÁNYOS DIÁKKÖRI TEVÉKENYSÉG HATÁROK NÉLKÜL, AZAZ A TUDOMÁNYOS UTÁNPÓTLÁS BIZTOSÍTÁSÁNAK ELSŐ LÉPCSŐJE}

A határon túli tudományosság szempontjából is alapvető kérdés a kutatói utánpótlás biztosítása, amelyben Magyarországon kiemelt szerepet játszik az Országos Tudományos Diákköri Konferencia (OTDK). Az OTDK-n hosszú ideje rendszeresen vesznek részt határon túli hallgatók és oktatók. ${ }^{8} \mathrm{Az}$ ő bekapcsolódásukat, az ennek alapját jelentő tudományos diákköri múhelymunka szervezését és a határon túli TDK kérdésének egységes, ugyanakkor az egyes országokhoz és az ottani felsőoktatáshoz, illetve szervezetekhez illeszkedő támogatását és gondozását 2010-ben kezdte meg az Országos Tudományos Diákköri Tanács (OTDT). Ezen év júniusában megállapodás született a Magyar Rektori Konferencia kihelyezett kolozsvári ülésén a romániai tudományos diákköri tevékenység tartalmi és operatív szervezési kereteiről, valamint az OTDK-ra történő becsatornázás folyamatairól. A megállapodást aláíró szervezetek magyarországi oldalról az OTDT mellett a Magyar Rektori Konferencia, romániai részről az Országos Magyar Diákszövetség, a Kolozsvári Magyar Egyetemi Intézet és az MTA Kolozsvári Akadémiai Bizottság voltak.

A megállapodás aláirását követően, az abban rejlő lehetőségeket felismerve született az a döntés, hogy a felvidéki, a kárpátaljai és a vajdasági felsőoktatási TDK-tevékenység segítésére is megkezdődjön a közös munka az OTDT, valamint az érintett felsőoktatási intézmények és szervezetek között. Az előkészítést követően 2011. február 4-én a Debreceni Egyetemen a felvidéki és a kárpátaljai TDK-ra vonatkozóan szándéknyilatkozat,

\footnotetext{
${ }^{8}$ ANDERLE Ádám: A magyar diákkörök mint országos mozgalom. In: Anderle Ádám (szerk.): A magyar tudományos diákköri konferenciák története (1951-2011). Budapest, Oktatáskutató és Fejlesztő Intézet, 2011. 85. p.

${ }^{9}$ Együttműködési szerződés a romániai felsőoktatásban tanuló magyar diákok tehetséggondozásának segítésére, Kolozsvár, 2010. június 11.
} 
a vajdasági TDK esetében pedig együttmúködési megállapodás aláírására került sor. ${ }^{10}$ A magyarországi aláírók az OTDT mellett a Magyar Rektori Konferencia és a Felsőoktatási Tudományos Tanács voltak.

Az egyes határon túli területek részéről az aláírók:

- Felvidék: Nyitrai Konstantin Filozófus Egyetem Közép-európai Tanulmányok Kar, Selye János Egyetem, Selye János Egyetem Hallgatói Önkormányzat, Diákhálózat;

- Kárpátalja: „Genius” Jótékonysági Alapítvány, Ungvári Nemzeti Egyetem Magyar Tannyelvű Humán- és Természettudományi Kar;

- Vajdaság: Vajdasági Magyar Felsőoktatási Kollégium, Vajdasági Magyar Akadémiai Tanács, Magyar Nemzeti Tanács Felsőoktatási és Tudományos Bizottsága.

A vajdasági megállapodáshoz csatlakozott a Debreceni Egyetem, a Magyarságkutató Tudományos Társaság, a szabadkai Magyar Tannyelvű Tanítóképző Kar és a Szabadkai Műszaki Főiskola.

A szerződésekkel kialakuló keretrendszer jelenti azt az alapot, amelyen az OTDT határon túli tevékenysége felépülhetett. A 2011. évi XXX. Jubileumi OTDK-n ennek a hatásai még nem voltak érzékelhetőek, az ezt követő időszakban azonban a határon túli TDK-konferenciák szervezésére irányuló nagyobb figyelem, illetve a határon túli oktatók bekapcsolódása az OTDT és szakmai bizottságai munkájába meghozta az eredményét.

Tekintettel a téma fontosságára, továbbá az elért eredményekre, 2013-ban első alkalommal vált lehetővé a Nemzeti Tehetség Program keretében biztosított támogatásnak köszönhetően, hogy a határon túli hallgatók és oktatók szervezetten vegyenek részt az OTDK-n. Ezen támogatás felhasználásával hívta életre az OTDT a TDK Határok Nélkül Programot (HTDK), amely az OTDK részvétel mellett egyre komolyabb (elsősorban) szakmai segítséget nyújtott és nyújt a helyi TDK tevékenységhez. A HTDK Program megvalósítója a Sapientia Hungariae Alapítvány, amely szervezet jelentős tapasztalattal rendelkezik a határon túli felsőoktatási feladatok és programok megvalósítása terén.

A XXXI. OTDK-n, kihasználva a lehetőséget, a szekciók tagozataiban pályamunkával részt vevő hallgatók és zsüritagok mellett úgynevezett határon túli megfigyelő státuszban is jöttek oktatók a konferenciára. Azokban a szekcióban pedig, ahol jelentős volt a határon túli résztvevők száma, külön szakmai és szabadidős programokat is szerveztek részükre, amelyeken további tudást és impulzusokat gyűjthettek. Ezzel lehetővé vált egy szélesebb kör számára, hogy saját tapasztalatokat szerezzen, kapcsolatokat építsen, amelynek nyomán hazatérve ő maga is TDK-s tevékenységbe, illetve annak témavezetőként történő segítésébe fogjon.

10 Együttműködési szándéknyilatkozat a felvidéki felsőoktatásban tanuló magyar diákok tehetséggondozásának segítésére, Debrecen, 2011. február 4.

Együttműködési szándéknyilatkozat a kárpátaljai felsőoktatásban tanuló magyar diákok tehetséggondozásának segítésére, Debrecen, 2011. február 4.

Együttműködési megállapodás a vajdasági felsőoktatásban tanuló magyar diákok tehetséggondozásának segítésére, Debrecen, 2011. február 4. 
Fontos előrelépést jelentett még ugyanebben az évben, hogy a határon túli TDK tevékenység támogatása is megoldódott a Nemzeti Tehetség Program meghívásos pályázatának keretében. Ennek keretösszege az első évben 5 millió forint volt, majd 2014-ben és 2015-ben 15,2 millió, 2016-tól fogva pedig 15 millió forint. Ez a folyamatos támogatási forrás stabilitást és kiszámíthatóságot teremtett a TDK tevékenység hátteréhez, amellyel az eredmények alapján jól éltek a támogatottak.

A 2013. évi OTDK-t követően az első szerződéses időszak tapasztalatainak feldolgozására 2014 tavaszán a HTDK Program megszervezte a HTDK Parlamentet, ahova meghívást kaptak a határon túli intézményi képviselők, hallgatók és az OTDT vezetősége, illetve szakmai bizottságainak elnökei. A többnapos rendezvény keretében folytatódott a közös munka, amelynek fókuszában maga a TDK tevékenység és annak fejlesztése állt.

Még 2012-ben, a XXXI. OTDK-t megelőzően született az a döntés, hogy a 2015. évi XXXII. OTDK Fizika, Földtudományok és Matematika Szekcióját Kolozsvárott tartják meg. Az első alkalommal határon túlra szervezett OTDK szekció szakmailag is rendkívül eredményesen sikerült, emellett a részt vevő hallgatók és oktatók számára egyaránt olyan élményt jelentett, ami az OTDK szereplés és szerepvállalás szokásos szerepkörén is jelentősen túlmutat.

A páros évben ismételten a szervezésé, a tervezésé és az előkészítésé volt a főszerep; a Il. HTDK Parlament emellett fontos mérföldkövet jelentett, hiszen a programot megelőzően az OTDT Elnöksége kezdeményezte az elért eredmények áttekintését, és a 2010-ben és 2011-ben megkötött megállapodások felülvizsgálatát. Ennek folyományaként új megállapodásokat dolgoztak ki az érintettek, amelyeket 2016. július 4-én írtak alá Gödöllőn, a II. HTDK Parlamenten. ${ }^{11}$ A megállapodások aláírója magyarországi részről az OTDT mellett ismételten a Magyar Rektori Konferencia volt, míg a határon túliak részéről

- a romániai felsőoktatás esetében a Romániai Magyar Diákszövetség és az Erdélyi Tehetségsegítő Tanács;

- a szerbiai felsőoktatás esetében a Vajdasági Felsőoktatási Kollégium, a Vajdasági Magyar Akadémiai Tanács, az Újvidéki Egyetem Magyar Tannyelvű Tanítóképző Kara, a Szabadkai Műszaki Főiskola, az Újvidéki Egyetem Bölcsészettudományi Kar Magyar Nyelv és Irodalom Tanszéke és a Vajdasági Magyar Doktoranduszok és Kutatók Szervezete;

- a szlovákiai és a csehországi felsőoktatás esetében a Szlovákiai Magyar Tudományos Diákköri Tanács, a Selye János Egyetem, a Nyitrai Konstantin Filozófus Egyetem Közép-európai Tanulmányok Kara, a Comenius Egyetem Magyar Nyelv és Irodalom Tanszéke és az Eperjesi Egyetem Magyar Nyelv és Kultúra Intézete;

\footnotetext{
11 Együttműködési szerződés a romániai felsőoktatásban tanuló magyar diákok tehetséggondozásának segítésére, Gödöllő, 2016. július 4. Együttműködési megállapodás a szerbiai felsőoktatásban tanuló magyar diákok tehetséggondozásának segítésére, Gödöllő, 2016. július 4. Együttműködési megállapodás a szlovákiai és csehországi felsőoktatásban tanuló magyar diákok tehetséggondozásának segítésére, Gödöllö, 2016. július 4.

Együttműködési megállapodás az ukrajnai felsőoktatásban tanuló magyar diákok tehetséggondozásának segítésére, Gödöllő, 2016 . július 4.
} 
- az ukrajnai felsőoktatás esetében a „Genius” Jótékonysági Alapítvány, a II. Rákóczi Ferenc Kárpátaljai Magyar Főiskola, az Ungvári Nemzeti Egyetem Magyar Tannyelvű Humán- és Természettudományi Kara, és a Kárpátaljai Felsőoktatási Tehetséggondozó Diáktanács voltak.

Az aláirókban bekövetkező változások mutatják, hogy a két megállapodás megkötése (2010-2011 és 2016) között eltelt időben milyen sokszínűvé vált a TDK iránti érdeklődés és a TDK működése.

A 2016-ban kötött szerződések egyrészt összegzik az eredményeket, másrészt rögzítik a további együttmúködési kereteket. A megállapodások ismételten fókuszba helyezték a TDK-t, és a Nemzeti Tehetség Programból folyamatosan biztosított forrással együtt tovább alapozták a beágyazottságát és ismertségét a határon túli felsőoktatásban.

A 2019. évi XXXIV. OTDK-t megelőzően erdélyi vonatkozásban a fentiek alapján az a döntés született, hogy az OTDT elismeri a Sapientia Erdélyi Magyar Tudományegyetem és a Partiumi Keresztény Egyetem által szervezett TDK-konferenciákat az OTDK-ra delegáló konferenciaként, illetve 2021-ben Kolozsvár ismét OTDK helyszín lesz: a Biológia Szekciót a Babeș-Bolyai Tudományegyetem Biológia és Geológia Kara rendezi.

Az OTDT azon kezdeményezése tehát, amely a határon túli TDK tevékenység támogatását tűzte ki célul, egyértelműen eredményesnek mondható. A megállapodások tényleges hatását megelőző négy OTDK (2005-2011) és a megállapodások megkötésének évét követő négy OTDK (2013-2019) számadatai ezt egyértelműen tükrözik. Mindebben szerepe van a kialakított keretrendszernek, amely azonban nem tudna múködni a HTDK Program munkatársai által elvégzett munka, a Nemzeti Tehetség Program támogatásai, de leginkább a határon túli hallgatók és oktatók aktivitása nélkül.

1. táblázat. A határon túli TDK-konferenciák adatai, 2004-2019

\begin{tabular}{|c|c|c|c|c|c|c|}
\hline Időszak & $\begin{array}{c}\text { TDK-kon- } \\
\text { ferenciák } \\
\text { szekcióinak } \\
\text { száma (db) }\end{array}$ & $\begin{array}{c}\text { A TDK-kon- } \\
\text { ferenciákon } \\
\text { bemutatott } \\
\text { pályamunkák } \\
\text { száma (db) }\end{array}$ & $\begin{array}{c}\text { A bemutatott } \\
\text { pályamunkák } \\
\text { szerző } \\
\text { hallgatóinak a } \\
\text { száma (fö) }\end{array}$ & $\begin{array}{c}\text { A bemutatott } \\
\text { pályamunkák } \\
\text { témavezetőinek } \\
\text { száma (fö) }\end{array}$ & $\begin{array}{c}\text { Az OTDK-n } \\
\text { bemutatott } \\
\text { pályamunkák } \\
\text { száma (db) }\end{array}$ & $\begin{array}{c}\text { Az OTDK-n } \\
\text { 1-3. helyezést } \\
\text { elérők száma } \\
\text { (fó) }\end{array}$ \\
\hline 2004-2011 & 224 & 1398 & 1611 & 1564 & 518 & 231 \\
\hline $2012-2019$ & 524 & 4111 & 5117 & 4843 & 1459 & 595 \\
\hline
\end{tabular}

IRODALOMJEGYZÉK

ANDERLE Ádám: A magyar diákkörök mint országos mozgalom. In: Anderle Ádám (szerk.): A magyar tudományos diákköri konferenciák története (1951-2011). Budapest, Oktatáskutató és Fejlesztő Intézet, 2011. 28-96. p.

BEALL, Jeffrey: Dangerous Predatory Publishers Threaten Medical Research. $=$ Journal of Korean Medical Science, 31. évf. 10. sz. 2016. 1511-1513. p. DOI: 10.3346/ikms.2016.31.10.1511

12 Saját összeállítás. Adatok forrása: OTDT Titkárság, intézményi TDK-konferenciák és az OTDK-k adatbázisa. 
BILICSI Erika - DÉR Ádám - LENCSÉS Ákos: Az Open Access támogatásának közép-európai gyakorlata. = Könyv, Könyvtár, Könyvtáros, 25. évf. 2. sz. 2016. 20-28. p.

GRINIECE, Elina - Alasdair REID - Jelena ANGELIS: Evaluating and Monitoring the Socio-Economic Impact of Investment in Research Infrastructures. Technopolis Group, 2015. DOI: 10.13140/RG.2.1.2406.3525/1

MAZZUCATO, Mariana. (2018). Mission-Oriented Research \& Innovation in the European Union. A ProblemSolving Approach to Fuel Innovation-Led Growth. Brussels, European Commission, 2018. DOI: 10.2777/360325

MERTON, Robert K.: The Matthew Effect in Science, II. Cumulative Advantage and the Symbolism of Intellectual Property = Isis, 79. évf. 4. sz. 1988. 606-623. p.

OECD (2015): Frascati Manual 2015. Paris, OECD Publishing, 2015. DOI: 10.1787/9789264239012-en

REICHER, Stephen D. - S. Alexander HASLAM - Arthur G. MILLER: What Makes a Person a Perpetrator? The intellectual, Moral, and Methodological Arguments for Revisiting Milgram's Research on the Influence of Authority = Journal of Social Issues. 70. évf. 3. sz. 2014. 393-408. p. DOI: 10.1111/josi.12067
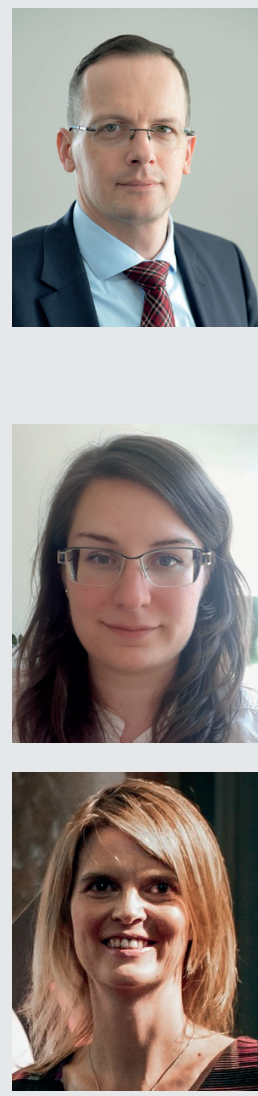

Dr. Szabó István (ORCID: 0000-0003-1682-0508)

Közgazdász, elnökhelyettesként koordinálja többek között a tudományos kutatások hazai finanszírozási rendszerét: az intézményi kiválósági programokat, az egyéni kutatói kiválósági programokat (OTKA), valamint a tudományos utánpótlást segítő Országos Tudományos Diákköri Konferencia (OTDK) és az Új Nemzeti Kiválóság Program (ÚNKP) szervezését.

Rigó-Ditzendy Orsolya

Szociológus, az NKFI Hivatal munkatársa, a Tématerületi Kiválósági Program 2020 programkoordinátora, doktorjelölt a Budapesti Corvinus Egyetem Szociológia Doktori Iskolájában.

\section{Dr. Cziráki Szabina}

Jogász, az Országos Tudományos Diákköri Tanács titkára, az NKFI Hivatal munkatársa, a Nemzeti Közszolgálati Egyetem Közigazgatástudományi Doktori Iskolájának hallgatója. 